\title{
Private school vouchers in developing countries: a survey of the evidence
}

\author{
Donald R. Baum, Brigham Young University
}

\begin{abstract}
This paper provides a narrative review of the existing rigorous evaluations of private school vouchers in developing countries. The findings suggest that school vouchers can be an effective means of expanding access to education, particularly for underserved populations (e.g., poorer students, girls, and students in undersupplied rural and urban communities). However, there is insufficient empirical evidence to sustain the expectation that universal school voucher policies will substantially raise the performance of an education system by increasing school choice and competition; and, universal vouchers are likely to reinforce socioeconomic stratification. However, as a catalyst for increased school attendance, targeted school vouchers have been effective at improving the performance of students on the margins of participation in the education system; and these outcomes can be achieved at lower costs than in the traditional public school system.
\end{abstract}

\section{Keywords}

Vouchers

School choice

Private schooling

Impact evaluation

Systematic review

International education

\section{Introduction}

The increasing role of non-government schools in the provision of education in low-income countries has been well-documented in recent years (Srivastava and Walford 2016). In developing countries across the globe, significant shares of students are choosing to enroll in private institutions; this trend has been particularly strong in low-income countries over the last two decades (Baum, Lewis, LuskStover, \& Patrinos 2014). In response to this growth, governments across the developing world have increased their interaction with stakeholders in the private education sector to establish a number of initiatives which combine public and private mixtures of school finance, operation, and ownership sometimes referred to as public-private partnerships (PPPs) (Patrinos et al. 2009). One of these policy initiatives - the private school voucher - is growing in implementation. Initially theorized as a means to increase competition and choice between schools, and thus quality and efficiency of delivered services (Friedman 1955), school voucher initiatives have recently been implemented in numerous countries across the globe. However, the research and technical guidance informing policy decisions on school vouchers is sometimes heavy on ideological rhetoric and correspondingly light on rigorous empirical evidence, thus potentially leading to unintended policy impacts. If policymakers in developing countries are to continue using school vouchers in their education reforms, it is imperative that they design these programs based on trustworthy scientific research and sound policy advice.

As a response to this reality, the intent of this paper is (i) to provide a review of the existing rigorous evaluations of school voucher programs in developing countries, and (ii) to provide guidance for 
education policymakers in their decisions regarding the appropriate contexts for adopting school voucher interventions to address issues of school quality, access, equity, or efficiency. As this review of evidence shows, school vouchers are neither the scourge nor the silver bullet for education systems that detractors and proponents commonly claim. However, given certain environmental conditions and under specific design decisions, school voucher programs can be effective tools for improving the ability for low-income students to access quality educational opportunities at an efficient cost to government. I address the viability of the school voucher claims to quality and cost-effectiveness, as well as draw explicit attention to the equity implications of school voucher initiatives.

\section{What are private school vouchers?}

A school voucher is a government payment for a child who chooses to attend a fee-paying private school. ${ }^{1}$ Within the defined parameters of what are often more generally termed public-private partnerships, voucher programs are considered a delivery-based PPP, with the state paying all or part of the student's education cost, while allowing non-state providers to deliver the actual educational services. These types of funding arrangements can be known by different names - such as tuition waivers/subsidies, tax-credit scholarships, or education savings accounts, among others - and can differ in terms of their design and structure. However, the defining characteristic of these programs is that state money follows the student to the school of her choice. ${ }^{2}$ Within other PPPs, such as government-subsidized (or 'aided') schools, private providers can also receive government funding; however, in these arrangements, funds do not follow students to their school of choice.

Vouchers can be universal, meaning they are made available to all students within a particular administrative jurisdiction, or they can be targeted (e.g., means-tested) to specific groups of students. The latter are more prevalent, with universal voucher programs being less common at national, state, or even municipal levels. For example, Colombia's PACES program provided vouchers only for those children residing in the poorest neighborhoods (Angrist et al. 2002), whereas, the nationally-universal voucher program of Chile provides funding to any student in the country to attend a non-state school (Elacqua 2012).

\section{Why are governments interested in school voucher programs?}

The implementation of many PPP programs in developing countries, including school vouchers, tend to be driven by a few common motivators. In a large number of developing countries, ministries of education face the following constraints:

- Incomplete access to basic education, particularly for at-risk demographic groups. Notwithstanding substantial growth in primary school enrollments for low-income countries during the Education for All decades (see Figure 1), a majority of countries continue to face challenges in providing equitable access for all students.

\footnotetext{
${ }^{1}$ Use of the term "private school" in the context of this paper refers to any formal education institution that is operated by a non-government entity. These can include schools run by for-profit or non-profit entities, non-governmental organizations (NGOs), local communities, as well as faith-based organizations.

${ }^{2}$ I use the term "voucher" generally to refer to any choice-based private school funding programs.
} 
Opportunities for educational access are spread unevenly across demographic groups, often in similar patterns across countries. Household and student characteristics such as wealth, gender, ethnicity, and geographic location are consistently powerful predictors of child participation in basic education (UNESCO 2015a). Where these disadvantages overlap, educational inopportunity is particularly compounded (UNESCO 2010, 2014). Such realities are consistent with Raftery \& Hout's (1993) hypothesis of maximally maintained inequality, which posits that educational inequalities persist until the most privileged social groups reach saturation of a particular education level (Ayalon and Shavit 2004). That is to say that the benefits of educational access will not be openly available to the most disadvantaged socioeconomic groups until their socioeconomically-advantaged counterparts maximize their opportunities. Thus, those least privileged groups will be the ones left out of universal primary access as long as there is persistent scarcity of educational supply.

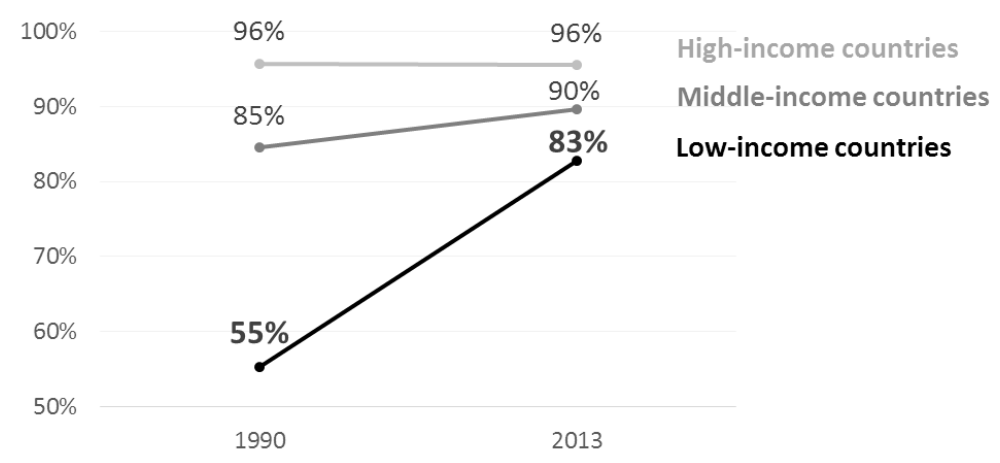

Fig. 1 Growth in primary net enrollment rates by country income levels, 1990 to 2013 (World Bank 2016)

As universal primary education has yet to be realized through the current supply of government education services, private school vouchers have been identified as one means of addressing this challenge, potentially catalyzing incentives (i) for private schools to increase school spaces, and (ii) to overcome demand-side constraints keeping kids out of school (Morgan et al. 2015). However, the topic of vouchers also raises concerns about reinforcing social stratification by favoring wealthier students to access higher quality private institutions (Arenas 2004). I address these issues in detail within the literature review and the discussion of implications for future voucher policies.

- Low learning outcomes. Although individual countries and international stakeholders have been buoyed by the global progress in primary school enrollments, perhaps an even larger concern for education systems has emerged in many low-income nations - what some have referred to as the 'global learning crisis' (Anderson and Strecker 2012; Berry et al. 2015). ${ }^{3}$ As presented above, countries striving to provide universal access to basic education face challenges in guaranteeing equitable access. These disparities are perhaps even larger with regards to student learning outcomes across countries. As reported by the EFA Global

\footnotetext{
${ }^{3}$ One in four youth in poor countries cannot read a basic sentence after completing four years of school (UNESCO 2014). In a recent assessment of student proficiency in East Africa, only 16 percent of grade-3 students across Kenya, Tanzania, and Uganda were able to pass grade-2 numeracy and literacy exams (Uwezo 2013).
} 
Monitoring Report (UNESCO, 2015a), across developing countries, the poorest fifth of households are, on average, six times less likely to be able to read than the wealthiest fifth of households.

To the naked eye, it appears that, with respect to learning outcomes, there is more reason to be optimistic with the results being produced in private schools. For example, in India, the percentage of grade- 5 children who are able to read a grade-2-level text fell from 54 percent in 2006 to 42 percent in 2014, while the percentage of grade 5 children in private schools reading at a grade-2 level has remained relatively steady, at just over 60 percent (Pratham 2015). In short, the achievement gap between public and private schools more than doubled from 9 to 20 percentage points between 2006 and 2014.

To be clear, much of this achievement gap is likely attributable to systematic differences between students in public and private schools rather than substantial differences in public and private school quality; indeed, the research on the quality of private schools in developing countries is highly mixed, with studies often finding performance differences to be largely attributable to differences in student compositions (Ashley et al. 2014). Nevertheless, it is not uncommon for policymakers to see such stark performance differences between these sectors and infer a substantial private school quality advantage. In addition to potential pre-existing differences in quality between public and private schools, school vouchers are appealing to some from a quality standpoint, as they may be able to raise student learning outcomes through multiple mechanisms, including: (i) increasing choice and competition within and between public and private schools (Kremer and Holla 2009); and (ii) incentivizing high performance of private schools by tying funding to certain performance standards (Baum et al. 2014).

- Overburdened government schools. The Education for All initiative has been influential in encouraging governments to expand access to primary education. In the 1990s and 2000s, many countries made progress through the elimination of public school tuition and nontuition fees, leading to rapid growth in participation in government primary schooling (Bategeka \& Okurut, 2015). Due in part to the enhanced efforts that low-income nations have made to increase educational access, many government school systems are overwhelmed, in terms of both access and quality. Overcrowded classrooms are a known feature of public schools in both Africa and South Asia. ${ }^{4}$ One of the determinants of private school choice in both of these regions is that private schools tend to have smaller class sizes (Ashley et al. 2014). For some, part of the draw towards private education interventions is to take advantage of the spare capacity in private schools to enroll more students, in addition to incentivizing new private providers to open through subsidies or vouchers, without further burdening the public school system.

- Insufficient budgets to meet all of these needs. Running through all of these common education challenges is the fact that insufficient resources are available to significantly increase expenditures on education. Countries across Africa are already spending on average 4.5

\footnotetext{
${ }_{4}$ The average primary school class size across Africa is 47 students. And, of 20 countries with available data in the last 5 years, more than half (11) have over 50 students per classroom at the primary school level (World Bank, 2016). Lessrecent estimates from South Asia suggest that the number of pupils per teacher in primary school range between 38 in Nepal to 55 in Pakistan and 57 in Bangladesh, with India at 43 (Nilsson, 2003).
} 
percent of GDP on education, only slightly below the OECD average of 5.3 percent (OECD 2015; World Bank 2016). Across the countries of South Asia and Latin America, an average of 3.8 percent and 4.7 percent of GDP is already being spent domestically on education. Given current levels of expenditure, it is perhaps unrealistic to expect many low-income nations to be able to substantially increase their rates of spending on education. Additionally, there are large gaps in the global financing available for education spending. The estimated finance gap between available domestic resources and the amount required to reach universal pre-primary, primary, and secondary education by 2030 is US $\$ 39$ billion; in low-income countries, this gap constitutes nearly half $(42 \%)$ of the total expected costs of meeting these education-related Sustainable Development Goals (UNESCO 2015b). Proponents of private schooling, as well as concerned stakeholders, have considered the role that private school vouchers might play to fill this gap, both in terms of finance, but also in the form of delivery - as private education has been shown to be consistently more cost-effective than government education provision. The evidence on this issue will be discussed in detail below.

\section{Conceptual framework}

Beginning in the 1950s, economist Milton Friedman began to theorize about the potential for school vouchers to break public monopolies in education delivery, using the power of the market through choice and competition to raise the quality of education (Friedman 1955, 1962). To date, the theoretical frameworks and philosophical arguments in favor of school vouchers in the United States and other industrialized country contexts are largely driven by the following aims:

a. Productive efficiency. To break down public monopolies in education and consequently increase competition between schools, with the proposed outcomes of increasing school quality and cost-effectiveness (Chubb and Moe 1990; Epple et al. 2015; Friedman 1962; Hoxby 2000).

b. Equity. To equalize educational opportunities by enabling at-risk students (e.g., poor students in urban locations) to escape perennially low-performing public schools (Epple and Romano 2012; West 2012; Witte 2001; Wolf 2008).

c. Freedom of choice. To provide families with increased options to choose a school that best aligns with their political, religious, social, and educational values (Cooper and Randall 2008; Levin 2002; Moe 2001).

Given these existing theoretical priorities, this review of the literature will highlight the impact of school vouchers on these issues. Additionally, there are notable differences between the educational environments in the United States and those in, say, Zambia or Nepal; thus, any discussion of vouchers in low-income countries must be sensitive to these differences. For instance, in the United States, and in most other upper-income countries, overall school enrollment is not a substantial policy concern (see Figure 1), whereas, in developing country contexts, deficiencies in schooling access remain a significant reality. As such, in the review of the research, I highlight issues unique to developing country contexts that should influence future voucher policy making.

\section{A review of the empirical evidence}

I provide here a narrative review of the existing rigorous evidence on school vouchers in developing countries - that is, those studies, which have implemented experimental or quasi-experimental identification strategies to estimate the causal impact of school voucher programs. The lessons learned 
from these experiences are used to inform policymakers of the reasonable expectations and critical questions to be considered when deciding whether a voucher system may be appropriate for their particular educational context.

\subsection{Chile}

Arguably, the voucher program that has received the most empirical attention in the global literature has been Chile's universal system, which was first introduced in 1981. A handful of rigorous quasiexperimental evaluations have attempted to provide causal estimates of the program's impact on educational access and quality. Overall, findings have been mixed. Hsieh \& Urquiola (2006), using a difference-in-differences approach, compare municipalities with the largest growth in private sector enrollment to those experiencing smaller growth; they find no evidence that the voucher program led to any student learning improvements. Using propensity score matching and difference-in-differences estimation, Lara et al. (2011) assess students who switch between voucher and non-voucher schools, and find that an education in a private voucher school offers a test-score premium on the order of 0.04 and 0.06 standard deviations. Bravo and colleagues' (2010) panel estimation approach finds that the voucher program has increased high school graduation rates by 3.6 percentage points and completion of at least two years of college by 2.6 percentage points.

With respect to issues of equity, Hsieh \& Urquiola (2006) find evidence that the growth in voucher participation has led to significant "cream-skimming" in the system - i.e., the quality of public schools deteriorated in areas where private schools expanded the fastest, as the best public-school students left for the private sector. These findings have resonance with the less rigorous research on the Chilean voucher program. Numerous studies have highlighted problems of academic sorting and socioeconomic segregation prohibiting disadvantaged students from accessing the highest quality voucher schools (Carnoy 1998; Elacqua 2012; Verger et al. 2016).

In response to these access constraints, the Chilean legislature passed an update to the national voucher policy in 2008 - Ley de Subvencion Preferencial (or SEP). The law introduced an incentive for private schools to enroll poorer students, offering a $64 \%$ increase in the voucher amount for the poorest $40 \%$ of students, and prohibiting schools from charging additional fees to these priority students (Elacqua 2012). A recent evaluation of this weighted voucher intervention found significant decreases in gaps of both enrollment and performance ( 0.2 standard deviations) for poor students in private schools versus those seen under the standard universal voucher (Neilson 2013). These findings highlight the differential benefits of voucher policies aimed at specific student populations, as opposed to those providing vouchers equally to all students, a procedure which is recognized in Chile and elsewhere to perpetuate inequalities of access to education (Epple and Romano 2008; Ladd et al. 2010).

\subsection{Colombia}

Colombia's Program for Increasing Secondary School Enrollment (PACES) operated from 1991 to 1997, providing students in low-income neighborhoods increased access to private secondary schools. The amount of the voucher in 1995 was US $\$ 190,{ }^{5}$ just over half of the $\$ 350$ public school unit cost (Angrist et al. 2002). However, in many cases, this amount did not cover the average full cost of private school attendance; on top of this amount, the average voucher recipient was paying $\$ 150$ annually in school matriculation and tuition fees. At its height, the PACES program covered 90,000 students,

${ }^{5}$ Roughly 8 percent of Colombia's GNI per capita 
roughly 1 percent of Colombia's secondary school enrollments (King et al. 1997). Exploiting the random assignment of voucher recipients via lottery, Angrist and colleagues (2002) found that, after three years of participation in the program, lottery winners finished $8^{\text {th }}$ grade at a rate of 10 percentage points above lottery losers, and performed 0.2 standard deviations above non-voucher recipients.

\subsection{Quetta, Pakistan}

In 1995, in attempt to expand participation of girls in primary education, the Balochistan Education Foundation initiated a school voucher program for girls in low-income neighborhoods in Quetta. The program provided girls with the average tuition cost to attend one of the community's lower-priced private schools. Kim, Alderman, and Orazem (1999) evaluated the program using a randomized control trial (RCT) design. Results from their study indicate that girls' enrollment in treatment neighborhoods increased by 33 percentage points. Additionally, although not eligible to receive school vouchers, enrollment for boys in treatment villages increased by 22 percentage points. These findings provide evidence of the ability for vouchers to increase enrollment of students through existing and newly-established private schools. Additionally, results draw attention to the impact that a voucher targeted to a specific demographic sub-group can have on their participation in the education system.

\subsection{Punjab, Pakistan}

The Foundation Assisted Schools (FAS) program in Punjab province, Pakistan was first initiated in 2005, and expanded progressively in subsequent years. Today, the program has grown to include over 1.3 million students across 3,000 participating schools (Punjab Education Foundation, 2016). Eligible private schools receive a monthly subsidy of less than half of the per-student expenditure in the public school system. In exchange, schools are required to admit students without charging any direct or indirect fees, and to openly advertise their free status. Additionally, schools must meet centrallydetermined standards on a semi-annual student performance assessment in order to maintain eligibility. Schools performing below established thresholds in a single year enter a probationary period; and, schools performing below the cutoff on two consecutive exams are permanently disqualified for funding.

Barrera-Osorio \& Raju (2011) carried out an evaluation of the FAS program using a regression discontinuity design. In 2007, 51 percent of FAS schools performed below the minimum performance standard, and thus faced the threat of expulsion given another year of underperformance. However, in the 2008 round of testing, nearly 100 percent of these probation schools performed above the minimum standard. Importantly, after performing above the minimum standard, schools experienced no further increase in performance. As such, the Punjab Education Foundation instituted a policy to progressively raise the minimum pass rate each year, to ensure that schools continue to improve (World Bank 2012). These findings suggest that accountability measures, which tie government funding to specific desired performance outcomes, have the ability to significantly impact school quality. But, the effects of government accountability depend on consistency in assessing performance and rigorous standards for promoting high quality education. Such accountability mechanisms have clearly been key determinants for maintaining quality of FAS schools.

\subsection{Uganda}


A program in Uganda that began in 2007 allows secondary students to choose between participating private schools. The program restricts schools from charging any tuition or fees beyond the price of the voucher amount (roughly $\$ 90$ per year). As of 2014 , there were 874 secondary schools participating in the program (Barrera-Osorio et al. 2015). The voucher is universal in nature, potentially providing access for all students; however, schools can select students based on academic or other criteria, and can continue to enroll non-voucher students for a fee greater than that of the voucher amount.

Evaluation findings suggest that the program has expanded schooling access in rural areas, including low-coverage communities, where entrepreneurs have used the funding to open new schools. BarreraOsorio and colleagues (2015) find that the voucher has contributed to significant increases in student enrollment (in the participating secondary grades as well as the non-participating primary grades) and survival, and that voucher schools are performing 0.20 to 0.25 standard deviations higher than nonvoucher schools on Uganda's National Assessment of Progress in Education. However, this performance advantage may be explained in part (or in full) by positive selection into voucher schools, as students in these schools appear to be from households that are (i) more highly educated, (ii) more financially secure, and (iii) more invested in the education of their children (Barrera-Osorio et al. 2015).

\subsection{Haiti}

In Haiti, more than 77 percent of all primary education enrollments are in private schools (World Bank 2016). However, the average household cost to attend a private school in Haiti is prohibitively high - roughly 32 percent of GNI per capita (Adelman and Holland 2015). The Government of Haiti launched a voucher program in 2007 - Programme de Subvention - with the aim of expanding access to primary education across the country. The voucher would cover the costs for students to attend a lower-priced private school, thus promoting the participation of schools (and students) within poorer communities (Adelman \& Holland 2015). In their randomized evaluation of the program, Adelman \& Holland (2015) found that the program substantially increased participation of out-of-school children, in addition to reducing the number of grade repeaters and the number of over-age students by roughly 10 percentage points. The results of this program suggest that private school vouchers can be a sufficient mechanisms to overcome the demand-side contraints keeping some kids from accessing education opportunities.

\subsection{Andhra Pradesh, India}

In Andhra Pradesh, India, a voucher intervention was implemented in 2008 across 180 rural villages. Qualifying schools receive roughly $\$ 80$ per year for each enrolled student - substantially less than the per-pupil cost in public schools. To avoid cream-skimming, schools that participate in the voucher program are not allowed to charge top-up fees. Muralidharan \& Sundararaman (2015) evaluated the program, randomizing the intervention by villages and pupils. After both two years and four years of the program, the researchers found that voucher recipients performed no better than non-recipients on tests of Telugu, math, English, and science/social science. However, private schools were found to be also teaching Hindi, a subject not taught in public school, and voucher recipients performed significantly higher on tests of Hindi than non-recipients. So, across the board, voucher recipients in private schools performed more or less on par with non-recipients in public schools. However, the authors note that these equivalent academic results were being produced at less than one-third the unit cost of public schools, a substantial advantage in terms of cost-efficiency. 


\subsection{Sindh, Pakistan}

In 2009, the Sindh province government launched a program - Promoting Low-Cost Private Schooling in Rural Sindh (PPRS) - with the intended aim of expanding access to primary education in previously underserved rural communities. The program would encourage entrepreneurs to open new private schools in selected rural villages by providing vouchers to students. To be eligible for funding, voucher-receiving schools were prohibited from charging students any additional fees.

In their RCT evaluating the program, Barrera-Osorio and colleagues (2013) found that vouchers increased enrollment of the target student population (ages 5 to 9) by 30 percentage points in treatment villages. Additionally, enrollment for older children in these villages increased by 12 percentage points (i.e., more older children enrolled in private school, paying tuition and non-tuition fees, simply due to the increased availability of schooling options). As a result of this growth in school enrollment, student test scores in treatment villages increased by 0.67 standard deviations village-wide, and by 2.01 standard deviations for those students who enrolled as a result of the voucher provision. Results from this study suggest that the introduction of school vouchers can have substantial impacts on student enrollment in underserved areas, providing sufficient incentives for new private schools to open. Moreover, such expansion in private provision and enrollment can be highly cost-effective: the monthly voucher was nearly half the monthly amount spent per student in government schools (World Bank 2016).

\subsection{Delbi, India}

In 2011, the ENABLE (Ensure Access to Better Learning Experiences) voucher program was initiated in the Shahdara slum area of East Delhi, with the aim of encouraging low-income households to access quality private education opportunities. In their randomized evaluation of the program, Wolf, Egalite, \& Dixon (2015) assess the causal effect of the ENABLE vouchers on student performance in the subjects of Hindi, English, and mathematics. Changes from baseline to the end of year two are compared between voucher (treatment) and non-voucher (control) students. The study finds significant impacts of the voucher program on student achievement in English - 0.15 standard deviations - but no effects in Hindi or mathematics. No findings are reported on the voucher's impact on student enrollment or attendance.

The significant English effect from this study falls in line with the existing school choice literature from India, which shows that school language of instruction is a strong determinant of selection into private schools - private schools are much more commonly English medium to attract students out of the public system (Baird 2009; Desai et al. 2009; Härmä 2009; Nambissan 2009; Singh and Sarkar 2012; Tooley et al. 2007). Thus, one potential reason voucher winners perform better in English is because they receive greater hours of English instruction as a result of increased participation in English medium private schools.

\subsection{Summary of the literature}

Far and away, the key takeaway from the existing research on school vouchers in developing countries is that these initiatives can be a particularly effective means of expanding access to education, particularly for underserved populations. Schools vouchers have been successfully used in a variety of country contexts to improve access to education for poor students, girls, and in underserved rural and 
urban communities. Vouchers have been successful in incentivizing entrepreneurs to establish new schools where government services previously did not reach. Vouchers have been effective in leveraging private schools to increase the enrollment of marginalized students. Additionally, vouchers have been a powerful tool for breaking down some of the demand-side constraints that keep traditionally disadvantaged households from accessing public or private education opportunities. In this regard, means-tested and otherwise targeted vouchers are socially progressive, and can be more equity enhancing than even universal public education. To maximize these equity effects, it is important that voucher programs restrict private schools from charging fees on top of the voucher amount; without these measures the system is likely to experience increases in social stratification, leaving the poorest segments of the student population out of participation.

The review of the existing voucher literature on student performance finds resonance with MacLeod and Urquiola (2013). Following their review of the scientific evidence on school choice, these authors conclude that there is "no a priori reason to believe that school choice will dramatically improve test scores." The findings presented above reinforce this assertion; there is insufficient empirical evidence to sustain the expectation that school voucher policies will substantially raise the performance of an education system by increasing levels of school choice. Rather, the overall evidence suggests that, on average, voucher students in private schools perform at equivalent levels as they would in public schools. As such, universal voucher programs should not be expected to produce substantial learning beyond what is being produced in existing public school systems. The literature suggests that forces of direct, outcomes-based accountability have stronger effects on school and student performance than the forces of choice and competition. Where the financial viability of private schools depends upon voucher funding, the potential for inducing higher performance through minimum performance standards is strong.

Notwithstanding the lack of evidence on the benefit of universal vouchers and increased competition for improving the performance of the entire education system, I find strong evidence in support of large learning benefits for at-risk student populations. As a catalyst for improved school attendance, private school vouchers have been shown to be very effective at improving the performance of those students on the margins of participation in the education system. I see in the literature substantial learning gains for those students whose participation in education is dependent on their reception of a voucher.

Lastly, the literature is highly consistent on the subject of cost-effectiveness, finding in nearly every country context that the cost of educating a student through a school voucher is less (and often substantially less) than educating a student in the government system. In sum, in developing country contexts, school vouchers can be an effective tool for increasing both participation and performance of students in the lower-income quintiles, for students in both urban and rural underserved communities, and for female students; and these outcomes can be achieved at substantially lower costs than by serving these students in public schools.

\section{What policy outcomes can a school voucher reasonably expect to achieve?}

When considering a school voucher policy as a viable education intervention in any country, the primary question for policy makers should be: “What main outcome does the policy hope to achieve?" Drawing 
upon the current research, there are four primary intended outcomes from school voucher policies in developing countries:

Outcome 1: To raise student learning across the entire education system via increased levels of choice and competition.

Outcome 2: To raise student learning for a targeted group of underperforming or otherwise underserved children.

Outcome 3: $\quad$ To maintain current levels of student learning through a more cost-effective delivery model.

Outcome 4: To increase access to schooling for currently underserved students (females, rural, poor, disabled students).

Given the existing experimental and quasi-experimental school voucher research, we can reasonably rule out Outcome 1 as an expected policy outcome. The intentions behind Outcome 1 suggest a universal voucher approach, seeking to boost the performance of the entire education system by raising levels of choice and competition in the marketplace. Unfortunately, the existing research on such programs does not find any consistent impacts on overall levels of student learning. And such voucher designs are further complicated by their tendency to favor the most privileged students, thereby counteracting efforts to increase equity. As such, given the current scientific knowledge, policymakers should be advised against the universal voucher as a means to improve general levels of student learning.

However, while the review of the research does not find sufficient evidence to support a universal school voucher framework, the evidence strongly suggests that properly designed voucher policies can adequately lead to Outcomes 2-4. I next consider the contexts in which private school vouchers may be effectively implemented.

\section{When should a voucher approach be considered?}

Previous frameworks have been presented by scholars, detailing the specific design features that should be considered when both assessing and creating school voucher programs. Levin (2002) first proposed a framework for the evaluation of school vouchers, informed by the empirical research in wealthy country contexts, primarily the United States. He proposed multiple indicators within the broad categories of (i) finance, (ii) regulation and (ii) support services to guide evaluators in assessing the design of voucher programs. Shafiq (2010) applies Levin's framework to present an approach for designing targeted vouchers in developing country contexts. While these frameworks provide insightful guidelines for policymakers to implement voucher policies, neither approach gives much guidance on determining whether a school voucher policy may be appropriate in the first place.

One of the key assertions of this paper is that private school voucher policies are not appropriate for all educational environments. There are certain constraints within education systems that school vouchers are best matched to address. And there are contexts in which a voucher policy would be illsuited to a country's particular educational challenges. Governments can estimate the predicted effectiveness of a proposed voucher program by first considering the contextual barriers in the system. For example, with regard to increasing enrollment: 
- Are there any groups of students who face demand-side constraints to accessing basic education (i.e., children whose education participation is currently restricted by direct (tuition, fees, uniforms, meals, etc.) or indirect (opportunity) costs)?

- Are there existing private schools that are simply not admitting sufficient numbers of underserved students?

- Are there any geographic locations with inadequate enrollment but an existing supply of private providers?

- Are there any underserved geographic locations where supply of both public and private schools is currently low (e.g., rural locations or urban slums)?

If policymakers can answer 'yes' to one or more of the questions above, a private school voucher could be designed to help increase student enrollment; and given the relative cost-effectiveness of private versus public schooling, it is likely to be a more efficient delivery model than expanding public services to meet all of these student access needs. With regard to the production of student learning, the following contextual questions can provide guidance to policymakers:

- Are there students (vulnerable students in particular) in perennially underperforming public schools that would be able to attend a higher quality (public or private) school with the assistance of a voucher?

- Is access of the most vulnerable students restricted to the lowest-cost private schools (e.g., only unregistered schools not subject to state oversight or quality assurance)?

- Would an influx of cash into the private school sector incentivize certain schools to agree to meeting increased achievement standards?

If policymakers can answer 'yes' to one or more of these questions, a private school voucher could be designed to help raise learning outcomes for targeted schools and student populations. In any scenario, the recommended approach would be for a voucher designed to meet the access and learning needs of specific student populations, as opposed to an open, universal voucher, which is unlikely to be a valuable contributor to any country's Education for All efforts.

\section{Conclusion}

After reviewing the existing rigorous evidence on the impacts of private school vouchers in developing countries, I find that voucher policies are most often adopted in attempt to reach one or more of the following outcomes: (1) to raise student learning across the entire education system; (2) to raise student learning for a targeted group of children; (3) to provide a more cost-effective education delivery model; or (4) to increase access to schooling for disadvantaged students. The evidence suggests that previously-implemented and evaluated voucher programs in developing countries have been successful in meeting all of these outcomes, with the exception of system-wide growth in student achievement (e.g., in universal voucher programs). Universal vouchers should not be expected to yield significant changes in the productive efficiency of education systems, and they should be anticipated to reinforce existing social stratification, subsidizing more privileged students to attend the highest quality schools.

However, targeted vouchers can be effective in contexts where there is low coverage of public education services, and where there are barriers to demand for certain students and communities. 
Vouchers offer incentives sufficient to motivate new private schools to open in both rural villages and urban slums. Vouchers can overcome cost-based constraints to educational access for those on the margins of participation. And students who are empowered to enroll in school as the result of receiving a voucher can be expected to increase in their knowledge and performance. Overall, when appropriately selected, vouchers offer a cost-effective mechanism for governments to reach students who are currently being left behind under universal public education approaches.

\section{References}

Adelman, M. A., \& Holland, P. (2015). Increasing access by waiving tuition: Evidence from Haiti (No. 7175). World Bank Policy Research Working Paper.

Anderson, A., \& Strecker, M. (2012). Sustainable development: A case for education. Environment: Science and Policy for Sustainable Development, 54(6), 3-16.

Angrist, J., Bettinger, E., Bloom, E., King, E., \& Kremer, M. (2002). Vouchers for private schooling in Colombia: Evidence from a randomized natural experiment. The American Economic Review, 92(5), 1535-1558.

Arenas, A. (2004). Privatization and vouchers in Colombia And Chile. International Review of Education, 50(3), 385-400.

Ashley, L. D., Mcloughlin, C., Aslam, M., Engel, J., Wales, J., Rawal, S., et al. (2014). The role and impact of private schools in developing countries (Journal Article).

Ayalon, H., \& Shavit, Y. (2004). Educational reforms and inequalities in Israel: The MMI hypothesis revisited. Sociology of Education, 77(2), 103-120.

Baird, R. (2009). Private schools for the poor: Development, provision, and choice in India. Gray Matters Capital.

Barrera-Osorio, F., Blakeslee, D. S., Hoover, M., Linden, L. L., Raju, D., \& Ryan, S. (2013).

Leveraging the private sector to improve primary school enrolment: Evidence from a randomized controlled trial in Pakistan.

http://www.riseprogramme.org/sites/www.rise.ox.ac.uk/files/7_Barrera_pprs_pakistan_work ing_paper.pdf. Accessed 17 August 2016

Barrera-Osorio, F., De Galbert, P., Habyarimana, J., \& Sabarwal, S. (2015). The impact of public-private partnerships on private school performance: Evidence from a randomized controlled trial in Uganda. http://www.riseprogramme.org/sites/www.rise.ox.ac.uk/files/5_ PPP_Uganda_Barreraetal.pdf. Accessed 21 July 2016

Barrera-Osorio, F., \& Raju, D. (2011). Evaluating public per-student subsidies to low-cost private schools: Regression-discontinuity evidence from Pakistan (No. 5638). http://papers.ssrn.com/sol3/papers.cfm?abstract_id=1822957. Accessed 25 July 2016

Baum, D. R., Lewis, L., Lusk-Stover, O., \& Patrinos, H. A. (2014). What matters most for engaging the private sector in education: A framework paper (No. 8). Washington, D.C.: The World Bank.

Berry, C., Barnett, E., \& Hinton, R. (2015). What does learning for all mean for DFID's global education work? International Journal of Educational Development, 40, 323-329. 
Bravo, D., Mukhopadhyay, S., \& Todd, P. E. (2010). Effects of school reformon education and labor market performance: Evidence from Chile's universal voucher system. Quantitative economics, 1(1), 47-95.

Carnoy, M. (1998). National voucher plans in Chile and Sweden: Did privatization reforms make for better education? Comparative Education Review, 42(3), 309-337.

Chubb, J. E., \& Moe, T. M. (1990). Politics, markets, and America's schools. Washington, D.C.: Brookings Institution Press.

Cooper, B. S., \& Randall, E. V. (2008). Fear and privatization. Educational Policy, 22(1), 204-227.

Desai, S., Dubey, A., Vanneman, R., \& Banerji, R. (2009). Private schooling in India: A new educational landscape. In S. Bery, B. Bosworth, \& A. Panagariya (Eds.), India Policy Forum (Vol. 5, pp. 1-38). SAGE Publications.

Elacqua, G. (2012). The impact of school choice and public policy on segregation: Evidence from Chile. International Journal of Educational Development, 32, 444-453.

Epple, D., \& Romano, R. (2008). Educational vouchers and cream skimming. International Economic Review, 49(4), 1395-1435.

Epple, D., \& Romano, R. (2012). Economic modeling and analysis of educational vouchers. Annual Review of Economics, 4(1), 159-183.

Epple, D., Romano, R. E., \& Urquiola, M. (2015). School Vouchers: A Survey of the Economics Literature (No. 21523). NBER. Cambridge, MA.

Friedman, M. (1955). The role of government in education. In R. A. Solo (Ed.), Economics and the public interest. New Brunswick: Rutgers University Press.

Friedman, M. (1962). Capitalism and freedom. Chicago: University of Chicago Press.

Härmä, J. (2009). Can choice promote Education for All? Evidence from growth in private primary schooling in India. Compare: A Journal of Comparative and International Education, 39(2), 151-165.

Hoxby, C. M. (2000). Does competition among public schools benefit students and taxpayers? American Economic Review, 90(5), 1209-1238.

Hsieh, C.-T., \& Urquiola, M. (2006). The effects of generalized school choice on achievement and stratification: Evidence from Chile's voucher program, 90, 1477-1503.

Kim, J., Alderman, H., \& Orazem, P. F. (1999). Can private school subsidies increase enrollment for the poor? The Quetta Urban Fellowship Program. The World Bank Economic Review, 13(3), 443465.

King, E., Rawlings, L., Gutierrez, M., Pardo, C., Torres, C., \& King, E. M. (1997). Colombia's targeted education voucher program: Features, coverage, and participation (No. 3). The World Bank.

Kremer, M., \& Holla, A. (2009). Improving Education in the Developing World: What Have We Learned from Randomized Evaluations? - Annual Review of Economics, 1(1):513. Annual Review of Economics, 1, 513-542.

http://www.annualreviews.org/doi/abs/10.1146/annurev.economics.050708.143323 
Ladd, H. F., Fiske, E. B., \& Ruijs, N. (2010). Parental choice in the Netherlands: Growing concerns about segregation (No. SAN10-02). http://eric.ed.gov/?id=ED524048. Accessed 19 July 2016

Lara, B., Mizala, A., \& Repetto, A. (2011). The effectiveness of private voucher education: Evidence from structural school switches. Educational Evaluation and Policy Analysis, 33(2), 119-137.

Levin, H. M. (2002). A comprehensive framework for evaluating educational vouchers. Educational Evaluation and Policy Analysis, 24(3), 159-174.

Moe, T. M. (2001). Schools, vouchers, and the American public. Washington, D.C.: Brookings Institution Press.

Morgan, C., Petrosino, A., \& Fronius, T. (2015). The impact of school vouchers in developing countries: A systematic review. International Journal of Educational Research, 72, 70-79. doi:10.1016/j.ijer.2015.04.010

Muralidharan, K., \& Sundararaman, V. (2015). The aggregate effect of school choice: Evidence from a two-stage experiment in India. The Quarterly Journal of Economics, 130(3), 1011-1066. doi:10.1093/qje/qjv013

Nambissan, G. B. (2009). The Indian middle classes and educational advantage. In M. W. Apple, J. Ball, Stephen, \& L. A. Gandin (Eds.), The Routledge international handbook of the sociology of education (pp. 285-295). London: Routledge.

Neilson, C. (2013). Targeted vouchers, competition among schools, and the academic achievement of poor students. Job market paper.

http://economics.sas.upenn.edu/system/files/event_papers/Neilson_2013_JMP_current.pdf. Accessed 25 July 2016

OECD. (2015). Education at a glance 2015: OECD indicators. OECD Publishing.

Patrinos, H. A., Barrera-Osorio, F., \& Guáqueta, J. (2009). The role and impact of public-private partnerships in education. Washington, D.C.: The World Bank.

Pratham. (2015). Annual status of education report (rural) 2014. New Delhi.

Raftery, A. E., \& Hout, M. (1993). Maximally maintained inequality: Expansion, reform, and opportunity in Irish education, 1921-75. Sociology of Education, 66(1), 41-62.

Shafiq, M. N. (2010). Designing targeted educational voucher schemes for the poor in developing countries. International Review of Education, 56(1), 33-50.

Singh, R., \& Sarkar, S. (2012). Teaching quality counts: How student outcomes relate to quality of teaching in private and public schools in India (No. 91). Oxford.

Srivastava, P., \& Walford, G. (2016). Non-state actors in education in the Global South. Oxford Review of Education, 42(5), 491-494.

Tooley, J., Dixon, P., \& Gomathi, S. V. (2007). Private schools and the millennium development goal of universal primary education: a census and comparative survey in Hyderabad, India. Oxford Review of Education, 33(5), 539-560.

UNESCO. (2010). EFA global monitoring report 2010: Reaching the marginalized. Paris. 
UNESCO. (2014). Teaching and learning: Achieving quality for all. Education for All Global Monitoring Report 2013-2014. Paris.

UNESCO. (2015a). Education 2030: Equity and quality with a lifelong learning perspective (No. 20). Paris.

UNESCO. (2015b). Pricing the right to education: The cost of reaching new targets by 2030 (No. 18). Paris.

Uwezo. (2013). Are our children learning? Literacy and numeracy across East Africa. Nairobi.

Verger, A., Bonal, X., \& Zancajo, A. (2016). What are the role and impact of public-private partnerships in education? A realist evaluation of the Chilean education quasi-market. Comparative Education Review, 60(2), 223-248.

West, E. G. (2012). Education vouchers in principle and practice. World Bank Research Observer, 12(1), 83-103.

Witte, J. F. (2001). The market approach to education: An analysis of America's first voucher program. Princeton: Princeton University Press.

Wolf, P. (2008). School voucher programs: What the research says about parental school choice. BYU Law Review, 2008(2), 415-446.

Wolf, P., Egalite, A., \& Dixon, P. (2015). Private school choice in developing countries: Experimental results from Delhi, India. In Pauline Dixon, Steve Humble, \& Chris Counihan (Eds.), Handbook of International Development and Education (pp. 456-471). Cheltenham, UK: Edward Elgar.

World Bank. (2012). Pakistan: Can low-cost private schools improve learning? Washington, D.C.

World Bank. (2016). EdStats. http://datatopics.worldbank.org/education/. Accessed 17 August 2016 